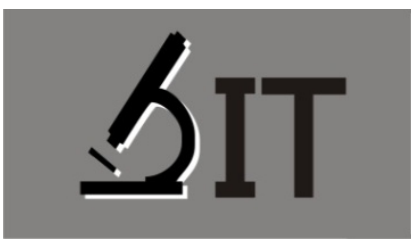

p-ISSN : 2597-8977

e-ISSN : 2597-8985

Nur Kurnaeni

SMP Negeri 4 Makassar

Sudarto

Universitas Negeri Makassar

Ramlawati

Universitas Negeri Makassar
JIT 3 (1) (2019) 1-11

JURNAL IPA TERPADU

http://ojs.unm.ac.id/index.php/ipaterpadu

\section{PENGARUH MODEL PEMBELAJARAN GUIDED DISCOVERY TERHADAP PENINGKATAN HASIL BELAJAR IPA PESERTA DIDIK KELAS VII SMP NEGERI 15 MAKASSAR (MATERI POKOK EKOSISTEM)}

Abstrak: Penelitian ini bertujuan untuk mengetahui pengaruh model pembelajaran guided discovery pada meteri ekosistem terhadap peningkatan hail belajar peserta didik kelas VII SMP Negeri 15 Makassar. Jenis penelitian yang dipilih adalah penelitian eksperimen semu (quasi eksperimen) dengan desain pretest-postest nonequivalent control group design. Populasi dalam penelitian ini adalah seluruh peserta didik kelas VII SMP Negeri 15 Makassar terdiri dari sepuluh kelas dengan jumlah keseluruhan peserta didik 340 Orang. Sampel penelitian ditentukan secara acak dengan teknik double random sampling yang terdiri dari dua kelas. Kelas pertama adalah kelas eksperimen yang diajar dengan model pembelajaran guided discovery dan kelas kedua adalah kelas kontrol yang diajar dengan model pembelajaran konvensional. Kelas pertama adalah kelas VII1 dengan 33 peserta didik dan kelas kedua adalah VII3 terdiri dari 35 peserta didik. Hasil penelitian menunjukkan bahwa (1) Hasil belajar IPA Peserta didik sebelum diajar dengan model pembelajaran konvensional pada kelas VII3 berada pada kategori rendah; (2) Hasil belajar IPA Peserta didik sesudah diajar dengan model pembelajaran konvensional pada kelas VII3 berada pada kategori sedang; (3) Hasil belajar IPA Peserta didik sebelum diajar dengan model pembelajaran guided discovery pada kelas VII1 berada pada kategori rendah; (4) Hasil belajar IPA Peserta didik sesudah diajar dengan model pembelajaran guided discovery pada kelas VII1 berada pada kategori tinggi; (5) Terjadi peningkatan yang lebih tinggi pada hasil belajar IPA Peserta didik sesudah diajar dengan model pembelajaran guided discovery pada kelas VIl1 dibandingkan hasil belajar IPA Peserta didik sesudah diajar dengan model pembelajaran konvensional pada kelas $\mathrm{VII3}$

Kata Kunci: Guided Discovery, Pembelajaran Konvensional, Hasil Belajar

Abstract: This research was aimed to detemine the effect of guided discovery applied of ecosistem material in increasing the ability of student SMP Negeri 15 Makassar. The research was quasi experiment with pretest-postest nonequivalent control group design. The population of the research were all of student of class VII at SMP Negeri 15 Makassar consisted of 10 classes with 340 students. The Sample of research were determined randomly by using group double random sampling technique and obtained two classes. The first class was the expereiment class which was taught by guided discovery learning and the second class was the 
control class which was taught by conventional learning. The first class was VII1 with 33 students and the second class was VII3 with 35 students. The result of the research reveral that (1) Results Students learn science before being taught by conventional learning models in seventh grade 3 are at the low category; (2) Science learning outcomes learners after being taught using conventional learning model in class $\mathrm{VII}_{3}$ is in the medium category; (3) Science learning outcomes Students before teaching with guided discovery learning model in class VII1 are in low category; (4) Science learning outcomes Learners after being taught with guided discovery learning model in class VII1 are in high category; (5) There is a higher increase in the learning outcomes of the students after being taught with the guided discovery learning model in class VII1 compared to the learning outcomes of the students after learning with the conventional learning model in class VII3.

Keywords: Guided Discovery, Conventional, Learning Outcomes.

\section{PENDAHULUAN}

Proses pembelajaran dalam pembelajaran IPA tentunya mengarah pada tujuan pendidikan, sehingga upaya pemerintah salah satunya adalah mengimplementasikan kurikulum yang mengarah kepada keaktifan peserta didik. Kurikulum IPA SMP menekankan pada pemberian pengalaman secara langsung kepada peserta didik dalam mempelajari peristiwa yang terjadi di lingkungan sekitar, kehidupan sehari-hari dan masyarakat modern yang sarat dengan teknologi. Untuk mencapai tujuan pendidikan, pendidik harus memiliki cara membimbing dan mengajar peserta didik sesuai dengan kondisi real kehidupan peserta didik atau kondisi sosial peserta didik (Yakub, 2014).

Melalui pembelajaran IPA terpadu dalam implemantasi Kurikulum 2013, peserta didik dapat memperoleh pengalaman langsung sehingga dapat menambah kekuatan untuk menerima, menyimpan, dan menerapkan konsep yang telah dipelajarinya. Dengan demikian peserta didik terlatih untuk dapat menemukan sendiri berbagai konsep yang dipelajari secara menyeluruh (holistik), bermakna, autentik, dan aktif. Berkembang atau tidaknya pengetahuan peserta didik bergantung pada tenaga pendidik. Hal ini merupakan tugas pendidik dalam memecahkan persoalan tersebut, dimana tenaga pendidik dapat mengembangkan keterampilan dalam mengajar, baik dari segi stretegi ataupun model pembelajaran.

Pada SMP Negeri 15 Makassar, pendidik lebih banyak menggunakan model pembelajaran langsung (direct intruction) yang bersifat konvensional. Hal ini dikarenakan kondisi peserta didik yang membutuhkan bantuan dari pendidik. Pendidik telah menggunakan model pembelajaran seperti inkuiri dan discovery akan tetapi peserta didik masih belum mampu membangun sendiri pengetahuannya dan membutuhkan bantuan dari pendidik, sehingga pendidik kembali kepada proses pembelajaran yang bersifat konvensional.

Model pembelajaran langsung (direct Intruction) yang hanya menerima penjelasan dari pendidik, dan hasilnya tergantung sejauh mana peserta didik memperhatikan penjelasan tersebut, hal ini biasa juga disebut teacher-centered yaitu pendidik sebagai pusat pembelajaran. Hal ini tentunya hanya melatih peserta didik untuk hanya sekedar menghapal materi IPA dalam waktu jangka pendek dan tidak dapat dipungkiri peserta didik akan mengalami kesulitan mengingat dalam jangka waktu panjang, sehingga berdampak terhadap hasil belajar IPA peserta didik. Hasil belajar peserta didik yang diperoleh berdasarkan observasi rata-rata hasil tes ujian peserta didik 
50,45 yang seharusnya peserta didik harus memperoleh rata-rata 75 (SMP Negeri 15 Makassar, 2016).

Untuk memecahkan masalah tersebut maka perlu dilakukan upaya antara lain berupa perbaikan model pembelajaran yang menfalisitasi terjadinya komunikasi antara pendidik dan peserta didik, sehingga mampu meningkatkan hasil belajar peserta didik, peneliti menerapkan model pembelajaran guided discovery pada pembelajaran IPA (khususnya materi ekosistem). Materi ekosistem merupakan materi yang memiliki banyak konsep dan membutuhkan pemahaman dari peserta didik. Untuk itu melalui pembelajaran dengan model guided discovery diharapkan peserta didik pada SMP Negeri 15 Makassar, dapat menemukan sendiri pengetahuannya untuk mengetahui konsep IPA (khususnya materi pokok ekosistem) melalui pengamatan.

Model pembelajaran merupakan suatu rencana atau pola yang digunakan untuk membentuk kurikulum (rencana pembelajaran jangka panjang) merancang bahan-bahan pembelajaran dan membimbing pembelajaran di kelas memandu proses pembelajaran dan membimbing pembelajaran di kelas. Menurut Joice dan Weill dalam (Huda, 2013) model pembelajaran sebagai rencana atau pola yang dapat digunakan untuk membentuk kurikulum, mendesain materi-materi intruksional dan memandu proses pembelajaran.

Discovery learning merupakan salah satu model pembelajaran kognitif yang dikembangkan oleh Bruner. Discovery Learning (penemuan) merupakan pencarian atau penyelidikan dalam pembelajaran dimana pendidik menciptakan situasi sehingga peserta didik dapat belajar sendiri. Peserta didik belajar melalui keterlibatan aktif dengan konsep dan prinsip-prinsip, peserta didik didorong untuk mempunyai pengalaman dan melakukan percobaan yang memungkinkan mereka menemukan prinsip-prinsip atau pengetahuan bagi dirinya. Jadi, dalam discovery learning yang sangat penting adalah peserta didik sungguh terlibat pada persoalan-persoalannya, menemukan prinsip-prinsip atau jawaban lewat suatu percobaan (Suparno, 2007).

Menurut Weimer (dalam Haryani, 2010) mengidentifikasi adanya 6 tipe discovery, yaitu:1) Discovery, 2) Discovery Teaching, 3) Inductive Discovery, 4) Semi-inductive Discovery, 5) Unguided or Pure Discovery atau Discovery murni, dan 6) Guided Discovery. Model pembelajaran discovery yang masih membutuhkan pengawasan dari pendidik disebut guided discovery yang merupakan salah satu model pembelajaran yang dapat digunakan untuk mengkonstruksikan pemikiran peserta didik dalam memecahkan masalah.

Model pembelajaran guided discovery yang merupakan model pembelajaran yang dapat digunakan untuk mengkonstruksikan pemikiran peserta didik dalam memecahkan masalah. Menurut Mayer (2004), guided discovery merupakan salah satu model pembelajaran yang bertujuan melatih peserta didik untuk menemukan konsep secara mandiri. Peserta didik berperan aktif dalam proses pembelajaran dengan menjawab berbagai pertanyaan atau persoalan dan memecahkan persoalan untuk menemukan suatu konsep. Di dalam pembelajaran guided discovery, pendidik menyajikan contoh-contoh, memandu untuk menemukan pola-pola dalam contoh-contoh tersebut, dan memberikan kesimpulan ketika peserta didik telah mampu mendeskripsikan gagasan yang telah di ajarkan oleh pendidik (Sulisyowati,dkk. 2012).

Sofa (dalam Hariyani, 2010) mengatakan bahwa model discovery merupakan model pembelajaran yang memerlukan proses mental, seperti mengamati, mengukur, menggolongkan, menduga, menjelaskan, dan mengambil kesimpulan. Pada kegiatan discovery pendidik hanya memberikan masalah dan peserta didik diminta untuk memecahkan masalah melalui percobaan.

Model pembelajaran guided discovery tersebut, digunakan untuk membangun konsep peserta didik di bawah pengawasan pendidik. Model Pembelajaran guided discovery merupakan proses kombinasi yang serasi antara pembelajaran yang terpusat pada pendidik (teachercentered) dan terpusat pada peserta didik (student-centered). Dalam model pembelajaran ini, pendidik memberikan kebebasan peserta didik untuk menemukan suatu konsep sendiri, karena dengan menemukan sendiri, peserta didik dapat lebih memahami apa yang mereka dapatkan 
tersebut sehingga dapat diingat lebih lama. Sedangkan pendidik hanya memberikan pengarahan atau petunjuk. Model pembelajaran ini dapat melatihkan keterampilan Peserta didik untuk menyelidiki dan memecahkan masalah secara mandiri (Aprilia \& Mulyaningsih, 2014).

\section{METODE}

Penelitian ini dilaksanakan di SMP Negeri 15 Makassar pada tahun ajaran 2017/2018 dengan populasi seluruh peserta didik kelas VII1 sampai VIl10 yang berjumlah 340 peserta didik. Penelitian ini, menggunakan desain pretest-postest nonequivalent control group design. Desain penelitian ini menggunakan pretest untuk mengukur kemampuan awal peserta didik, dan posttest dengan memastikan kedua kelas adalah homogen. Teknik penarikan sampel yang digunakan adalah teknik double random samling, yaitu teknik pengambilan sampel dari populasi secara acak tanpa memperhatikan strata yang ada dalam populasi.

Pengambilan sampel dilakukan dengan memilih secara acak 10 kelas yang dijadikan 2 kelas, kemudian secara acak memilih satu kelas kontrol dan satu kelas eksperimen. Model pembelajaran guided discovery sebagai kelas eksperimen adalah $\mathrm{VII}_{1}$ dan model pembelajaran konvensional sebagai kelas kontrol adalah VII. Teknik pengumpulan data dalam penelitian data dalam penelitian ini adalah dengan memberikan tes hasil belajar pretest dan posttest kepada peserta didik dan lembar observasi keterlaksanaan model pembelajaran guided discovery. Peserta didik diberikan lembar tes yang berbentuk pilihan ganda 25 butir soal untuk ranah kognitif yang meliputi; ingatan $\left(C_{1}\right)$, pemahaman $\left(C_{2}\right)$, aplikasi $\left(C_{3}\right)$, dan menganalisis $\left(C_{4}\right)$. Setiap item memiliki satu pilihan jawaban benar adalah 1 dan skor untuk jawaban salah adalah 0.

Data yang diperoleh dalam penelitian ini akan dianalisa dengan menggunakan teknik statistik yakni teknik analisis deksriptif dan statistik inferensial. Statistik deksriptif digunakan untuk mendeksripsikan tingkat hasil belajar yang diperoleh peserta didik setelah diajar dengan menggunakan model pembelajaran guided discovery dan model pembelajaran konvensional. Hal ini dimaksudkan untuk mengetahui skor rata-rata, standar deviasi, variansi, skor tertinggi (maksimum), skor terendah (minimum), dan distribusi frekuensi.

Analisis $\mathrm{N}$-gain untuk melihat peningkatan dari pretest dan posttest. $\mathrm{N}$-gain adalah perbandingan antara selisih skor posttest-skor pretest dengan selisih skor maksimum skor pretest. $\mathrm{N}$-gain disebut juga skor ternomalisasi.

$$
\mathrm{N} \text {-gain }=\frac{\text { skor posttest }- \text { skor pretest }}{\text { skor maksimum }- \text { skor pretest }}
$$

Peningkatan hasil belajar dapat dilihat dari tingkat perolehan $\mathrm{N}$-gain yang terdapat tiga kategori yaitu:
a. Tinggi = N-gain $\geq 0,70$
b. Sedang $=0,30 \leq N$-gain $<0,70$
c. Rendah = N-gain $<0,30$

Statistik analisis inferenresial digunakan untuk menguji hipotesis penelitian, sebelum melakukan pengujian hipotesis, dilakukan pengujian dasar-dasar analisis yaitu uji normalitas data digunakan untuk mengetahui apakah data-data yang digunakan berdistribusi normal atau tidak. Pada pengujian ini digunakan rumus Chi-kuadrat sebagai berikut :

$$
X^{2}{ }_{\text {hitung }}=\sum_{\mathrm{i}=1}^{\mathrm{k}} \frac{(\mathrm{Oi}-\mathrm{Ei})^{2}}{\mathrm{Ei}}
$$


$\mathrm{X}^{2}$ menunjukkan Chi-kuadrat, $\mathrm{O}_{i}$ menunjukkan frekuensi yang diperoleh dari data penelitian, $E_{i}$ menunjukkan frekuensi yang diharapkan dan $k$ menunjukkan banyaknya kelas interval. Kriteria pengujian apabila $\mathrm{x}^{2}$ hitung $<\mathrm{x}_{\text {tabel }}^{2}$ dengan $\mathrm{dk}=(\mathrm{k}-1)$ pada taraf signifikan $\alpha=0,05$ maka data dikatakan berdistribusi normal.

Adapun untuk pengujian homogenitas dilakukan dengan menggunakan uji-F, dengan rumus:

$$
\mathrm{F}=\frac{\text { Varians terbesar }}{\text { Varians terkecil }}
$$

Kriteria pengujian apabila $\mathrm{F}_{\text {hitung }}<\mathrm{F}_{\text {tabel }}$ dengan $\mathrm{dk}$ pembilang dan penyebut pada taraf signifikan $\alpha=0,05$ maka data dikatakan berdistribusi homogen.

Uji perbedaan rata-rata data hasil pretest dan posttest pada $\mathrm{N}$-gain. Uji ini bertujuan untuk mengetahui apakah terjadi peningkatan hasil belajar IPA peserta didik kelas VII SMP Negeri 15 Makassar.

Uji ini bertujuan untuk mengetahui apakah terjadi peningkatan hasil belajar IPA peserta didik kelas VII SMP Negeri 15 Makassar dengan menggunakan model pembelajaran guided discovery lebih tinggi daripada model pembelajaran konvensional, dimana statistiknya $\mathrm{H}_{1}: \mu_{1}>\mu_{2}$. Menurut Sugiyono (2014), rumus uji t yang digunakan adalah:

$$
t=\frac{\overline{X_{1}}-\overline{X_{2}}}{S \sqrt{\frac{1}{n 1}+\frac{1}{n 2}}}
$$

Dengan $\overline{X_{1}}$ menunjukkan rata-rata nilai pada kelas eksperimen, $\overline{X_{2}}$ menunjukkan rata-rata nilai kelas kontrol. n1 menunjukkan jumlah peserta didik kelas eksperimen, n2 menunjukkan jumlah peserta didik kelas kontrol. $\mathrm{S}$ menunjukkan simpangan baku atau standar deviasi. Kriteria pengujian adalah $\mathrm{H}_{0}: \mu_{1} \leq \mu_{2}$ melawan $\mathrm{H}_{1}: \mu_{1}>\mu_{2}$, kriteria pengambilan kesimpulannya adalah $\mathrm{H}_{0}$ diterima jika $t_{\text {hitung }}>t_{\text {tabel }}$ dan sebaliknya $H_{1}$ diterima jika $t_{\text {hitung }}<t_{\text {tabel. }}$

\section{HASIL DAN PEMBAHASAN}

Adapun hasil perhitungan statistik deksriptif dari data hasil belajar IPA peserta didik kelas $\mathrm{VII}_{1}$ sesudah dibelajarkan dengan menggunakan model pembelajaran guided discovery dan hasil belajar IPA peserta didik kelas $\mathrm{VII}_{3}$ sesudah dibelajarkan dengan menggunakan model pembelajaran konvensional dapat dilihat pada Tabel 1 berikut.

\section{Tabel 1. Hasil Belajar IPA Peserta Didik Kelas Eksperimen dan Kontrol}

\begin{tabular}{ccccc}
\hline \multirow{2}{*}{ Statistik } & \multicolumn{2}{c}{ Kelas } & Eksperimen & \multicolumn{2}{c}{ Kelas Kontrol } \\
\cline { 2 - 5 } & Pretest & Posttest & Pretest & Posttest \\
\hline Jumlah Sampel & 33 & 33 & 35 & 35 \\
Skor Tertinggi & 16 & 23 & 15 & 22 \\
Skor Terendah & 5 & 13 & 5 & 10 \\
Skor Rata-Rata & 9,5 & 18,34 & 9,6 & 15,7 \\
Standar Deviasi & 2,9 & 2,9 & 2,97 & 3,32 \\
Varians & 8,41 & 8,41 & 8,82 & 11,02 \\
Rentang Skor & 11 & 10 & 10 & 11 \\
\hline
\end{tabular}


Berdasarkan Tabel 1. diperoleh gambaran bahwa hasil belajar IPA peserta didik kelas eksperimen yang dibelajarkan dengan menggunakan model pembelajaran guided discovery menunjukkan bahwa skor tertinggi yang dicapai saat pre test adalah 16, skor terendah adalah 5 . Sedangkan skor rata-rata yang dicapai adalah 9,5. Skor tertinggi yang dicapai saat posttest adalah 23, skor terendah adalah 13, sedangkan skor rata-rata yang dicapai adalah 18,34. Untuk hasil belajar IPA peserta didik kelas kontrol yang dibelajarkan dengan menggunakan pembelajaran konvensional menunjukkan bahwa skor tertinggi yang dicapai saat pre test adalah 15, skor terendah adalah 5, sedangkan skor rata-rata yang dicapai adalah 9,6, skor tertinggi yang dicapai saat posttest yang dicapai adalah 22, skor terendah 10, sedangkan skor rata-rata yang dicapai adalah 15,7 .

Adapun persentase hasil belajar peserta didik pada kelas eksperimen dan kelas kontrol. pada Tabel 2 berikut ini.

Tabel 2. Persentase Hasil Belajar IPA Peserta Didik Kelas Eksperimen dan Kelas Kontrol

\begin{tabular}{cccccc}
\hline \multirow{2}{*}{ Interval Nilai } & \multirow{2}{*}{ Kualifikasi } & \multicolumn{2}{c}{ Kelas } & Eksperimen & \multicolumn{2}{c}{ Kelas Kontrol } \\
\cline { 3 - 6 } & & $\mathbf{F}$ & Persentase (\%) & F & Persentase (\%) \\
\hline $21-25$ & Sangat Tinggi & 10 & 30,3 & 3 & 8,57 \\
$16-20$ & Tinggi & 15 & 45,45 & 14 & 40 \\
$11-15$ & Cukup & 8 & 24,24 & 15 & 42,9 \\
$6-10$ & Rendah & 0 & 0 & 3 & 8,57 \\
$0-5$ & Sangat Rendah & 0 & 0 & 0 & 0 \\
\hline & Jumlah & $\mathbf{3 3}$ & $\mathbf{1 0 0}$ & $\mathbf{3 5}$ & $\mathbf{1 0 0}$ \\
\hline
\end{tabular}

Berdasarkan Tabel 2 diatas menunjukkan bahwa pada kelas eksperimen yang dibelajarkan dengan model pembelajaran guided discovery persentase nilai peserta didik paling banyak pada kategori sangat tinggi sebanyak 10 Orang (30.3\%), kategori tinggi sebanyak 15 Orang (45,45\%), kategori cukup sebanyak 8 Orang (24,24\%). Tidak ada skor peserta didik pada ketegori rendah dan sangat rendah. Sedangkan pada kelas kontrol yang dibelajarkan dengan model pembelajaran konvensional persentase nilai peserta didik pada kategori sangat tinggi sebanyak 3 Orang $(8,57 \%)$, kategori tinggi sebanyak 14 Orang (40\%), kategori cukup sebanyak 15 Orang (42,9\%), kategori rendah sebanyak 3 Orang $(8,57 \%)$, tidak ada skor peserta didik pada sangat rendah.

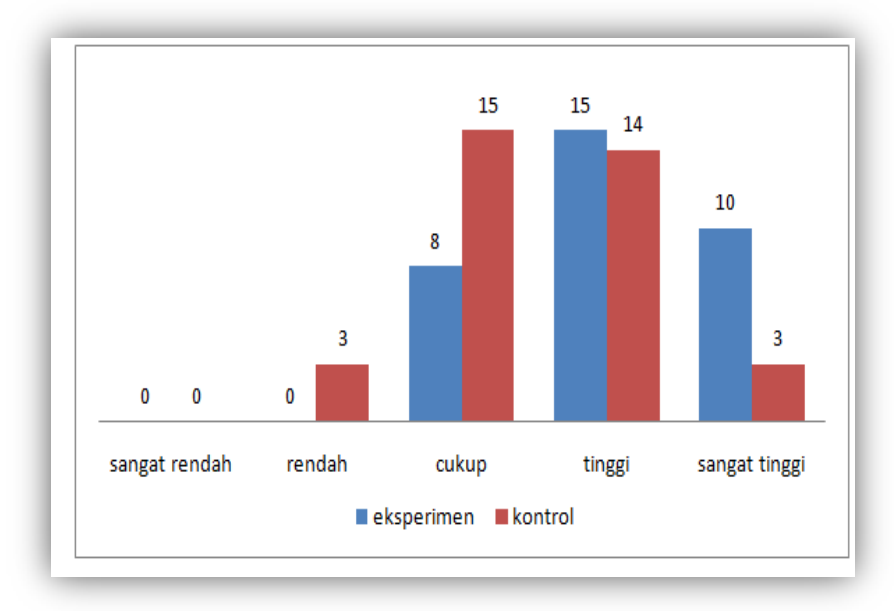

Gambar 1. Histogram Kategori Skor Hasil Belajar IPA 
Uji N-gain adalah untuk mengetahui ada tidaknya peningkatan dari hasil belajar IPA materi pokok ekosistem peserta didik. Adapun hasil belajar tersebut pada tabel berikut:

Tabel 3. Distribusi Frekuensi Hasil Belajar dengan Uji N-Gain

\begin{tabular}{cccccc}
\hline \multirow{2}{*}{ Interval } & Kategori & \multicolumn{2}{c}{ Kelas } & Eksperimen & \multicolumn{2}{c}{ Kelas Kontrol } \\
\cline { 3 - 6 } & & F & Persentase (\%) & F & Persentase (\%) \\
\hline$>0,7$ & Tinggi & 12 & $36 \%$ & 4 & $8,57 \%$ \\
$0,3<\mathrm{N}>0,7$ & Sedang & 17 & $52 \%$ & 21 & $71 \%$ \\
$<0,3$ & Rendah & 4 & $12 \%$ & 10 & $14 \%$ \\
\hline
\end{tabular}

Dari hasil analisis dengan menggunakan $\mathrm{N}$-gain diperoleh hasil belajar pada kelas ekperimen dengan kategori tinggi sebanyak 12 peserta didik dengan persentase $36 \%$, kategori sedang sebanyak 17 peserta didik dengan persentase 52\%, kategori rendah sebanyak 4 peserta didik dengan persentase $12 \%$. Sedangkan hasil belajar pada kelas Kontrol dengan kategori tinggi sebanyak 4 peserta didik dengan persentase 8,57\%, kategori sedang sebanyak 21 peserta didik dengan persentase $71 \%$, kategori rendah sebanyak 10 peserta didik dengan persentase $14 \%$. Hasil analisis uji $\mathrm{N}$-gain menunjukkan hasil belajar peserta didik meningkat dengan menggunakan model pembelajaran guided discovery.

Analisis pencapaian skor peserta didik ini ditinjau pada materi ekosistem terdiri dari 6 indikator, dapat dilihat pada Tabel 4.

Tabel 4. Persentase Pencapaian Hasil Belajar Peserta Didik tiap Indikator Kelas Eksperimen dan Kelas Kontrol

\begin{tabular}{|c|c|c|c|c|}
\hline \multirow{2}{*}{ No } & \multirow{2}{*}{ Indikator } & \multirow{2}{*}{$\begin{array}{l}\text { No. } \\
\text { Soal }\end{array}$} & \multicolumn{2}{|c|}{ Persentase Pencapaian } \\
\hline & & & Eksperimen & Kontrol \\
\hline 1 & $\begin{array}{l}\text { Menyebutkan pengertian ekosistem dan } \\
\text { membedakan ekosistem berdasarkan proses } \\
\text { terbentuknya }\end{array}$ & $\begin{array}{l}4,5,6,7 \\
8\end{array}$ & $76 \%$ & $65 \%$ \\
\hline 2 & $\begin{array}{l}\text { Mengidentifikasi peranan komponen biotik dan } \\
\text { abiotik dalam ekosistem }\end{array}$ & $\begin{array}{c}11,12,13 \\
14\end{array}$ & $77 \%$ & $68 \%$ \\
\hline 3 & $\begin{array}{l}\text { Mendeskripsikan pengertian individu, populasi, } \\
\text { komunitas }\end{array}$ & $\begin{array}{c}1,2,3,9 \\
10,24\end{array}$ & $74 \%$ & $59 \%$ \\
\hline 4 & Menjelaskan pola interaksi dalam ekosistem & $\begin{array}{c}17,22 \\
23\end{array}$ & $65 \%$ & $62 \%$ \\
\hline 5 & $\begin{array}{l}\text { Memahami konsep saling ketergantungan dan } \\
\text { ekosistem }\end{array}$ & $\begin{array}{l}16,18 \\
20,21\end{array}$ & $72 \%$ & $59 \%$ \\
\hline 6 & $\begin{array}{c}\text { Mengamati gambar dan menentukan tingkat } \\
\text { tropik yang terdapat dalam ekosistem serta } \\
\text { perpindahan energi }\end{array}$ & $\begin{array}{l}15,19 \\
25\end{array}$ & $81 \%$ & $68 \%$ \\
\hline & Rata-rata & & $74 \%$ & $64 \%$ \\
\hline
\end{tabular}

Selain dianalisis secara deksriptif, data hasil penelitian ini juga dianalisis secara inferensial dengan statistik uji-t untuk pengujian hipotesis. Hasil pengujian normalitas skor $\mathrm{N}$-gain hasil belajar IPA peserta didik kelas eksperimen dan kelas kontrol dengan menggunakan chi-kuadrat dapat dilihat pada Tabel 5 berikut. 
Tabel 5. Hasil Pengujian Normalitas Hasil Belajar IPA Kelas Eksperimen dan Kontrol

\begin{tabular}{lcccc}
\hline \multicolumn{1}{c}{ Kelas } & $\mathbf{x}_{\text {hitung }}{ }^{2}$ & $\mathbf{A}$ & $\mathbf{d k}$ & $\mathbf{x}_{\text {tabel }}{ }$ \\
\hline Kelas Eksperimen & 7,07 & 0,05 & 5 & 11,07 \\
Kelas Kontrol & 5,74 & 0,05 & 5 & 11,07 \\
\hline
\end{tabular}

Pada Tabel 5 di atas dapat dilihat bahwa dari hasil pengujian untuk kelas eksperimen diperoleh $\chi^{2}$ hitung $=7,07$ untuk $\alpha=0.05 \mathrm{dan} \mathrm{dk}=\mathrm{k}-1=6-1=5$, maka diperoleh $\chi_{\text {tabel }}^{2}=\chi_{(0,95)(5)}^{2}=$ 11,07. Dengan demikian $\chi^{2}$ hitung $<\chi_{\text {tabel }}^{2}(7,07<11,07)$. Untuk hasil pengujian kelas kontrol diperoleh $\chi_{\text {hitung }}=5,74$. Untuk $\alpha=0.05$ dan $\mathrm{dk}=\mathrm{k}-1=6-1=5$, maka diperoleh $\chi_{\text {tabel }}^{2}=\chi_{(0,95)(3)}{ }^{2}=11,07$, dengan demikian $\chi^{2}$ hitung $<\chi_{\text {tabel }}^{2}(5,74<11,07)$ yang berarti hasil belajar IPA peserta didik berasal dari populasi yang berdistribusi normal. Setelah kedua kelompok sampel penelitian dinyatakan berdistribusi normal, selanjutnya dicari nilai homogenitas varians data posstest hasil belajar IPA kelas eksperimen dan kelas kontrol, kriteria pengujian apabila $F_{\text {hitung }}<F_{\text {tabel }}$ maka data bersifat homogen.

Sebaliknya jika, $F_{\text {hitung }}>F_{\text {tabel }}$ data tidak homogen, dengan derajat kebebasan penyebut dan pembilang $d k=(n-1)$ pada taraf signifikansi $\alpha=0,05$. Berdasarkan analisis dengan taraf nyata $\alpha=$ 0,05 diperoleh nilai $F_{\text {hitung }}$ dan $F_{\text {tabel }}$ untuk hasil belajar IPA, $F_{\text {hitung }}=1,394$ dengan $F_{\text {tabel }}=1,80$. Karena $F_{\text {hitung }}<F_{\text {tabel }}$ dimana 1,394 $<1,80$ hal ini menunjukkan bahwa data dalam penelitian ini homogen. Dapat dilihat pada Tabel 6 berikut ini.

Tabel 6. Hasil Uji Homogenitas Posttest Kelas Eksperimen dan Kontrol

\begin{tabular}{lll}
\hline \multicolumn{1}{c}{ Statistik } & Kelas eksperimen & Kelas kontrol \\
\hline $\mathrm{N}$ & 33 & 35 \\
$\mathrm{~S}$ & 0,18 & 0,15 \\
$\mathrm{~S}^{2}$ & 0,032 & 0,023 \\
$\mathrm{~F}_{\text {hitung }}$ & \multicolumn{2}{c}{1,44} \\
$\mathrm{~F}_{\text {tabel }}$ & \multicolumn{2}{c}{1,80} \\
\hline
\end{tabular}

Pengujian hipotesis penelitian ini menggunakan uji dua pihak dengan uji-t sehingga diperoleh nilai $t_{\text {hitung }}$ untuk hasil belajar IPA sebesar 4,12 sedangkan $t_{\text {tabel }}$ adalah sebesar 1,67. Pengujian selengkapnya dapat dilihat pada lampiran $\mathrm{F}$. Dari hasil perhitungan diperoleh $\mathrm{t}_{\text {hitung }}$ $(4,12)>t_{\text {tabel }}(1,67)$, kriteria pengujian adalah : untuk uji dua pihak: $H_{0}: \mu=\mu_{0}$ melawan $H_{1}: \mu \neq \mu_{0}$, kriteria pengambilan kesimpulannya adalah $\mathrm{H}_{0}$ diterima jika t-tabel $>\mathrm{t}$-hitung, dan sebaliknya $\mathrm{H}_{1}$ diterima jika t-tabel < t-hitung.

Tabel 7. Hasil Uji Hipotesis

\begin{tabular}{lll}
\hline \multicolumn{1}{c}{ Statistik } & \multicolumn{1}{c}{$\begin{array}{c}\text { Kelas } \\
\text { eksperimen }\end{array}$} & Kelas kontrol \\
\hline Jumlah sampel & 33 & 35 \\
Skor rata & 0,6 & 0,43 \\
Varians $\left(\mathrm{S}^{2}\right)$ & 0,032 & 0,023 \\
Standar deviasi & 0,18 & 0,15 \\
$t_{\text {hitung }}$ & & 4,12 \\
$\mathrm{~T}_{\text {tabel }}$ & & 1,67 \\
\hline
\end{tabular}

Berdasarkan hasil analisis data diatas, menunjukkan bahwa $t_{\text {tabel }}=1,67<t_{\text {hitung }}=$ 4,12, hal ini berarti hipotesis nol ( $\mathrm{Ho}$ ) ditolak dan $\mathrm{H} 1$ diterima. Sehingga dapat disimpulkan bahwa model pembelajaran guided discovery berpengaruh terhadap peningkatan hasil belajar IPA 
(materi ekosistem) kelas VII SMP Negeri 15 Makassar, pada taraf signifikan $\alpha=0,05$. Hasil penelitian ini, didukung oleh hasil penelitian Widiadnyana, dkk (2014) dimana terdapat perbedaan pemahaman konsep IPA dan sikap ilmiah yang signifikan antara peserta didik yang belajar menggunakan model discovery learning dengan peserta didik yang dibelajarkan dengan menggunakan model pengajaran langsung.

Adapun Permana (2016) mengungkapkan bahwa terdapat perbedaan yang signifikan antara peserta didik yang dibelajarkan dengan menggunakan motode guided discovery learning dengan yang dibelajarkan secara konvesional dimana hasil belajar peserta didik yang dibelajarkan dengan menggunakan motode guided discovery learning lebih tinggi dibandingkan peserta didik yang dibelajarkankan secara konvensional pada materi Fisika.

Berdasarkan pengamatan selama proses pembelajaran terlihat bahwa suasana pembelajaran terlihat lebih hidup pada kelas eksperimen dibandingkan kelas kontrol, peserta didik terlihat lebih bersemangat mengikuti proses pembelajaran, dan lebih mengembangkan hasil pemikirannya, selain itu peserta didik terlihat lebih aktif secara berkelompok, dalam proses pembelajaran peserta didik mengamati lingkungan sekolah.

Pada proses pembelajaran berlangsung ada upaya yang dilakukan peserta didik dalam menyelesaikan masalah yang dimana pendidik ikut serta membimbing dan membantu mengembangkan keterampilan proses yang meliputi mengamati, mengajukan pertanyaan, membuat hipotesis, mengumpulkan data, serta membuat kesimpulan dalam memecahkan masalah (Bilfaqih, 2015). Sehingga peserta didik akan mengalami dua pengalaman belajar yaitu pengalaman mental dan pengalaman sosial. Pengalaman mental diperoleh dari indra pendengaran dan penglihatan, informasi yang didapatkan berdasarkan indra pendengaran diperoleh dari penjelasan yang diberikan pendidik sedangkan indra penglihatan berasal dari penemuan peserta didik itu sendiri. Penemuan tersebut akan selalu diingat oleh peserta didik daripada harus mendengar penjelasan dari pendidik. Pengalaman sosial diperoleh pada saat peserta didik berkelompok melakukan percobaan sehingga mereka lebih terlibat aktif dalam proses pembelajaran. Pengalaman yang diperoleh peserta didik digunakan untuk mengambil kesimpulan secara spesifik (Purwanto dkk, 2012).

Dalam materi ekosistem terdapat beberapa konsep yang mesti dipahami oleh peserta didik, dengan menggunakan model pembelajaran guided discovery bila diterapkan dengan baik tentunya peserta didik akan mendapat peluang yang lebih besar untuk mengetahui lebih banyak tentang IPA (materi ekosistem) dibandingkan dengan model pembelajaran konvensional, dikarenakan proses belajar peserta didik yang menemukan konsep sendiri melalui serangkaian data atau informasi yang diperoleh melalui pengamatan atau percobaan. Selain itu, pendidik lebih kreatif menciptakan situasi yang dapat membuat peserta didik belajar aktif menemukan pengetahuan sendiri, hal ini sesuai dengan teori Bruner yang menyarankan agar peserta didik dapat membangun konsep dan prinsip. Dalam kegiatan ini, peserta didik dapat menambah pengetahuan dan keterampilan secara simultan (Sani, 2013).

Adanya hasil belajar yang lebih tinggi disebabkan karena model pembelajaran guided discovery membuat peserta didik lebih aktif dalam proses pembelajaran, mengalami langsung apa yang sedang dipelajari akan lebih banyak mengaktifkan indera daripada hanya mendengarkan orang lain atu pendidik menjelaskan. Membangun pemahaman dari pengalaman langsung akan lebih mudah daripada membangun pemahaman dari uraian lisan pendidik. Berdasarkan uraian tersebut yang dapat dilakukan agar peserta didik memahami IPA khususnya pada materi ekosistem adalah menerapkan model pembelajaran guided discovery khususnya bagi peserta didik kelas VII SMP Negeri 15 Makassar. 


\section{KESIMPULAN}

1. Hasil belajar IPA peserta didik sebelum dibelajarkan dengan model pembelajaran konvensional pada kelas $\mathrm{VII}_{3}$ berada pada kategori rendah.

2. Hasil belajar IPA peserta didik sesudah dibelajarkan dengan model pembelajaran konvensional pada kelas $\mathrm{VII}_{3}$ berada pada kategori sedang.

3. Hasil belajar IPA peserta didik sebelum dibelajarkan dengan model pembelajaran guided discovery pada kelas VII1 berada pada kategori rendah.

4. Hasil belajar IPA peserta didik sesudah dibelajarkan dengan model pembelajaran guided discovery pada kelas VII1 berada pada kategori tinggi.

5. Terjadi peningkatan yang lebih tinggi pada hasil belajar IPA peserta didik sesudah dibelajarkan dengan model pembelajaran guided discovery pada kelas VIl1 dibandingkan hasil belajar IPA peserta didik sesudah dibelajarkan dengan model pembelajaran konvensional pada kelas VII3

\section{DAFTAR PUSTAKA}

Aprilia \& Mulyaningsi, 2014. Penerapan Perangkat Pembelajaran Materi Kalor melalui Pendekatan Saintifik dengan Model Pembelajaran Guided Discovery Kelas X SMA. Jurusan Fisika, FMIPA, Universitas Negeri Surabaya. Jurnal Inovasi Pendidikan Fisika (JIPF) Vol. 03 No. 03.

Bilfaqih Y, M \& Nur Qomarudin. 2015. Esensi Penyusunan Materi Pembelajaran Daring. Deepublish. Diakses 23 Agustus 2016, dari Google play.

Haryani A, 2010. Penerapan Model Pembelajaran Guided Discovery Pada Materi Pokok Kalor Untuk Meningkatkan Hasil Belajar Peserta Didik Kelas Vii A Mts Darul Ulum Beringin Semarang Semester Gasal Tahun Pelajaran 2010/2011. Skripsi. Fakultas Tarbiyah Institut Agama Islam Negeri Walisongo Semarang.

Huda,M. 2013. Model-model pengajaran dan pembelajaran. Yogyakarta: Pustaka Pelajar.

Permana, 2016. Pengaruh Metode Penemuan Terbimbing Terhadap Motivasi dan Hasil Belajar Fisika Peserta Didik MAN MODEL Makassar. Program Pascasarjana UNM Makassar.

Purwanto, Nugroho, dan Wiyanto, 2012. Penerapan Model Pembelajaran Guided Discovery Pada Materi Pemantulan Cahaya Untuk Meningkatkan Berpikir. Kritis. Jurusan Fisika, Universitas Negeri Semarang, Indonesia. Unnes physics Education Journal 1 (1) (2012). http://journal.unnes.ac.id/sju/indekx.php/upej

Suparno, P. 2007. Metodologi Pembelajaran Fisika Konstruktvistik \& Menyenangkan.Yogyakarta: Universitas Sanata Dharma.

Sulistyowati, Widodo, dan Sumarni, 2012. Pengaruh Pembelajaran Guided Discovery Learning Terhadap Kemampuan Pemecahan masalah Kimia. Jurusan Kimia FMIPA Universitas Negeri Semarang. Chem in Edu 2(1) (2012). Chemistry In Education.http://Journal.Unnes.Ac.Id/Sju/Index. php/Chemined

Suparno, P. 2007. Metodologi Pembelajaran Fisika Konstruktvistik \& Menyenangkan.Yogyakarta: Universitas Sanata Dharma.

Widiadnyana, 2014. Pengaruh Model Discovery Learning Terhadap Pemahaman Konsep IPA dan Sikap Ilmiah Siswa SMP. E-Journal Program Pascasarjana Universitas Pendidikan Ganesha Program Studi IPA (Volume 4 Tahun 2014). Diakses 27 Mei 2017.

Wisudawati \& Sulistyowati, 2014. Metodolologi Pembelajaran IPA. Jakarta:Bumi Aksara.

Yakub \& Vico hisbanarto, 2014. System Informasi Manajemen Pendidikan. Yogjakarta: Graha Ilmu. 
Nur Kurnaeni

Sudarto

Ramlawati 